\title{
PENINGKATAN HASIL BELAJAR SISWA MELALUI MODEL QUANTUM TEACHING DAN MEDIA PALANG ARAHKU
}

\section{Dwi Wijayanti, Murtono, dan Lintang Kironoratri}

Universitas Muria Kudus

Email: dwiw71196@gmail.com, murtono@umk.ac.id, lintang.kironoratri@umk.ac.id

\section{Info Artikel}

Sejarah Artikel:

Diserahkan 20 Juli 2020

Direvisi 28 Juli 2020

Direvisi 12 November 2020

Disetujui 14 November 2020

\section{Keywords:}

palang arahku quantum teaching, learning outcomes,

\begin{abstract}
This study aims to describe the improvement of learning outcomes (knowledge and skills) as well as the teaching skills of fourth grade teachers at SDN 1 Gondoharum on theme 6 My goals by using Quantum teaching learning models assisted by PALANG ARAHKU.

The type of research is Classroom Action Research. This research was conducted with 27 research subjects and teachers which lasted for 2 cycles. Each cycle consists of 4 stages, namely planning, implementation, observation, and reflection

The results of the study in the first cycle of the knowledge domain of IPS and Indonesian students in classical terms gained $68.7 \%$ (good). Then it increased in cycle II to $86.99 \%$ (very good). In the realm of skill cycle I gained a percentage of $71.5 \%$ (good) increased in cycle II to $87.5 \%$ (very good). The results of teacher teaching skills have increased. In cycle I gained a percentage of $71 \%$ (good) and cycle II increased to $85 \%$ (very good). Based on the results of cycle I and cycle II of the Quantum teaching model of grade IV students at SDN 1 Gondoharum Kudus.
\end{abstract}

\section{Abstrak}

Penelitian ini bertujuan untuk mendiskripsikan peningkatan hasil belajar (ranah pengetahuan dan keterampilan siswa) serta keterampilan mengajar guru kelas IV SDN 1 Gondoharum pada tema 6 Cita-citaku dengan menggunakan model pembelajaran Quantum teaching berbantuan media PALANG ARAHKU.

Jenis penelitian yang digunakan adalah Penelitian Tindakan Kelas. Penelitian ini dilaksanakan dengan subjek penelitian sebanyak 27 siswa dan guru yang berlangsung selama 2 siklus. Setiap siklus terdiri dari 4 tahap yaitu perencanaan, pelaksanaan, pengamatan, dan refleksi

Hasil penelitian pada siklus I ranah pengetahuan siswa muatan IPS dan Bahasa Indonesia secara klasikal memperoleh $68,7 \%$ (baik). Kemudian meningkat pada siklus II menjadi $86,99 \%$ (sangat baik). Pada ranah keterampilan siklus I memperoleh persentase 71,5\% (baik) meningkat pada siklus II menjadi 87,5 \% (sangat baik). Hasil keterampilan mengajar guru mengalami peningkatan. Pada siklus I memperoleh persentase $71 \%$ (baik) dan siklus II meningkat menjadi $85 \%$ (sangat baik). Berdasarkan hasil siklus I dan siklus II model Quantum teaching berbantuan media PALANG ARAHKU dapat meningkatkan hasil belajar siswa kelas IV SDN 1 Gondoharum Kudus. 


\section{PENDAHULUAN}

Pendidikan adalah salah satu sarana penting untuk menghasilkan manusia yang memiliki pengetahuan, keterampilan dan sumber daya manusia yang tinggi di era sekarang ini. pendidikan sangat erat kaitannya dengan kurikulum dan proses pembelajaran. Kurikulum di Indonesia banyak mengalami perubahan disesuaikan dengan perkembanga zaman. Seperti sekarang ini kurikulum yang digunakan adalah kurikulum 2013 yang menekankan pada pembelajaran tematik. Ardianti, dkk (2015) menjelaskan bahwa pembelajaran tematik merupakan pembelajaran terpadu yang menggunakan tema untuk mengaitkan beberapa muatan mata pelajaran sehingga memberikan pengalaman bermakna kepada peserta didik.

Dalam pelaksanaan kurikulum 2013 keberhasilan pencapaian tujuan pendidikan ditentukan oleh proses pembelajaran yang dialami peserta didik dalam belajar diharapkan mampu mengalami perubahan baik aspek pengetahuan, sikap dan keterampilan. Untuk mencapai tujuan tersebut peserta didik bukan hanya dituntut sekedar mendengar dan mencatat, akan tetapi aktivitas peserta didik dalam proses berpikir. Namun, kondisi yang terjadi saat ini pembelajaran hanya ditekankan pada aspek pengetahuan saja. Guru menjelaskan materi dan siswa mendengarkan. Hal ini membuat siswa bosan dan jenuh dalam pembelajaran. Selain itu model pembelajaran yang digunakan kurang bervariasi, sehingga proses pembelajaran menjadi kurang menarik dan terkesan monoton.

Berdasarkan wawancara dan observasi yang telah dilakukan pada tanggal 27 Juli 2019 di SDN 1 Gondoharum dengan guru dan siswa kelas IV terdapat beberapa permasalahan. Beberapa faktor penyebabnya yaitu dari guru, siswa, media pembelajaran dan sumber belajar. Kebanyakan siswa mengalami permasalahan pada muatan Bahasa Indonesia dan IPS. Muatan IPS dianggap terlalu banyak materi dan hafalan sehingga sulit untuk dipahami. Sedangkan pada muatan Bahasa Indonesia dianggap membosankan karena terlalu banyak bacaan.

Permasalahan selanjutnya guru masih mendominasi dalam pembelajaran serta guru kurang mampu memilih model pembelajaran dan media pembelajaran yang menarik bagi siswa. Selain permasalahan dari guru, permasalahan juga timbul dari siswa yang belum memiliki motivasi untuk menerima pembelajaran yang berlangsung. Kedua hal tersebut menyebabkan interaksi antar guru dan siswa kurang.
Beberapa permasalahan tersebut membuat hasil belajar siswa kurang maksimal khususnya pada muatan IPS dan Bahasa Indonesia. Dikatakan hasil belajar kurang maksimal karena nilai rata-rata pada muatan IPS dan Bahasa Indonesia berada di bawah KKM. Hal ini dibuktikan dengan data nilai kelas IV muatan IPS dari 27 siswa yang tidak tuntas sebanyak 15 siswa yang tidak tuntas dengan persentase ketuntasan IPS mencapai $44,44 \%$ dari keseluruhan siswa kelas IV. 55,56\% siswa belum memenuhi ketuntasan belajar pada muatan IPS. Hal tersebut sama halnya pada muatan Bahasa Indonesia dari 27 siswa yang tidak tuntas sebanyak 14 siswa yang tidak tuntas dengan persentase ketuntasan Bahasa Indonesia mencapai 48,14\%. Oleh karena itu $51,86 \%$ siswa belum memenuhi ketuntasan belajar pada muatan Bahasa Indonesia. Dalam hal ini peneliti mengambil tema 6 Cita-citaku muatan IPS dan Bahasa Indonesia.

Untuk mengatasi masalah tersebut, maka diperlukan suatu upaya untuk membuat suasana belajar yang lebih menarik. Sehingga dibutuhkan inovasi dalam pembelajaran. Seperti penggunaan model pembelajaran yang mampu mengaktifkan siswa, baik aktif secara individu maupun aktif secara kelompok. Melalui keaktifaan siswa diharapkan dapat meningkatkan hasil belajar peserta didik.

Salah satu model pembelajaran yang digunakan yaitu model Quantum teaching. Menurut Shoimin (2014) Pembelajaran Quantum teaching adalah pengubahan belajar yang meriah, dengan segala nuansanya. Model Quantum teaching diartikan sebagai suatu orkestrasi bermacam-macam interaksi yang sudah ada dalam momen belajar. Interaksi-interaksi itu mencakup unsur-unsur baik belajar efektif yang mempengaruhi kesuksesan siswa secara menyeluruh.

Dalam tema Cita-citaku model Quantum teaching dirasa cocok dengan materi khususnya pada muatan IPS dengan materi sumber daya alam dan Bahasa Indonesia dengan materi puisi. Berdasarkan permasalahan yang telah dipaparkan, pada muatan IPS dengan model Quantum teaching siswa dapat menggali informasi mengenai materi dari beberapa pertanyaan yang telah disajikan yang dapat dikerjakan secara kelompok. Pada muatan Bahasa Indonesia dengan Quantum teaching siswa tidak hanya membaca materi saja, tetapi sambil bermain. Sehingga tidak menimbulkan kejenuhan. Diantoro, dkk (2020) menyampaikan bahwa model Quantum Teching lebih melibatkan siswa saat proses pembelajaran, sehingga proses 
Dwi Wijayanti, Murtono, dan Lintang Kironoratri

PENINGKATAN HASIL BELAJAR SISWA MELALUI MODEL QUANTUM TEACHING ....

WASIS: Jurnal Ilmiah Pendidikan. Volume 1 Nomor 2, November 2020, hlm. 80-85

pembelajaran menjadi lebih nyaman dan menyenangkan.

Penerapan model Quantum Teaching tersebut diperlukan pelengkap seperti penggunaan media pembelajaran yaitu PALANG ARAHKU. Media tersebut dirancang untuk menguji pengetahuan yang diperoleh peserta didik dari penyajian kelas dan belajar kelompok dengan menggunakan langkah model Quantum teaching. Media tersebut berisi kartu pertanyaan, kartu zonk, dan kartu kejutan yang telah disiapkan. Amalia, dkk (2020) menyatakan bahwa hadirnya media pembelajaran dalam kegiatan pembelajaran akan membantu guru dalam menyampaikan pesan pembelajaran dan membantu siswa untuk memahami konsep pembelajaran.

Tujuan penelitian ini yaitu 1) mendeskripsikan peningkatan keterampilan mengajar guru melalui penerapan model Quantum teaching berbantuan media PALANG ARAHKU pada tema 6 muatan Bahasa Indonesia dan IPS kelas IV SDN 1 Gondoharum, 2) mendeskripsikan peningkatan hasil belajar siswa melalui penerapan model Quantum teaching berbantuan media PALANG ARAHKU pada tema 6 muatan Bahasa Indonesia dan IPS kelas IV SDN 1 Gondoharum.

\section{METODE PENELITIAN}

Penelitian ini menggunakan jenis Penelitian Tindakan Kelas (PTK) dengan menggunakan model Kemmis dan Mc. Taggart. Sumadayo (2013) menyebutkan prosedur penelitian yang digunakan dalam model Kemmis dan Mc. Taggart terdiri dari 4 tahapan yaitu perencanaan (plan), pelaksanaan tindakan (action), observasi (observation) dan refleksi (reflection). Penelitian ini akan dilakukan sebanyak 2 siklus setiap siklus terdiri dari 2 pertemuan dengan subjek penelitian siswa kelas IV SDN 1 Gondohrum yang berjumlah 27 siswa pada tema 6 Cita-citaku.

Teknik pengumpulan data dalam penelitian ini yaitu wawancara, observasi, tes serta dokumentasi. Wawancara digunakan untuk memperoleh informasi sebelum diadakan tindakan. Observasi digunakan untuk memperoleh data hasil belajar ranah keterampilan siswa dan keterampilan mengajar guru. Tes digunakan untuk memperoleh data hasil belajar ranah pengetahuan. Dokumentasi digunakan untuk mengumpulkan data berupa foto yang dibutuhkan dalam penelitian. Analisis data yang digunakan dalam penelitian ini adalah analisis data kualitatif dan kuantitatif.
Indikator keberhasilan yang harus dicapai dalam penelitian adalah (1) Keterampilan mengajar guru dengan menerapkan model pembelajaran Quantum teaching berbantuan media PALANG ARAHKU tema cita-citaku dikatakan meningkat apabila persentase mencapai 75\% dengan kriteria baik dan berhasil (2) Hasil belajar siswa pada tema cita-citaku menggunakan model pembelajaran Quantum teaching berbantuan media PALANG ARAHKU pada siswa kelas IV SDN 1 Gondoharum dapat dikatakan meningkat apabila rata-rata klasikal ranah pengetahuan mencapai $70 \%$ dengan kategori baik dan ranah keterampilan mencapai $70 \%$ dengan kategori baik, sesuai dengan KKM yang ditentukan yaitu 70 untuk muatan Bahasa Indonesia dan IPS.

\section{HASIL DAN PEMBAHASAN}

Pelaksanaan penelitian tindakan kelas dilakukan sebanyak 2 siklus dengan subjek penelitian siswa kelas IV SDN 1 Gondoharum sebanyak 27 siswa. Pelaksanaan penelitian peneliti menggunakan model pembelajaran Quantum teaching berbantuan media PALANG ARAHKU.

\section{Penerapan Model Quantum teaching dan media PALANG ARAHKU.}

Penerapan model Quantum teaching dan media PALANG ARAHKU melalui beberapa tahap yaitu penyajian kelas (tumbuhkan), membentuk kelompok (namai), penyampaian masalah (alami), pembentukan kelompok dan diskusi kelompok (alami), siswa mencatat jawaban dann mempresentasikan di depan kelas. (ulangi), memberikan apersepsi (rayakan). Tahap penyajian kelas dilakukan dengan pengajaran langsung dan melaksanakan tanya jawab antara guru dengan siswa agar tercipta suasana pembelajaran yang aktif dan menyenangkan. Pada saat penyajian kelas siswa harus memperhatikan, memahami, dan menguasai penjelasan yang disampaikan oleh guru maupun yang diperoleh dari proses tanya jawab.

Tahap membentuk kelompok, merupakan tahap dimana siswa dibagi menjadi beberapa kelompok secara heterogen. Tujuan dari pembentukan kelompok ini agar siswa lebih memahami materi bersama dengan teman satu kelompoknya. Pratiwi, dkk (2018) menyatakan bahwa kegiatan dalam kelompok dapat mengembangkan kemampuan kerjasama siswa. Pada tahap kelompok siswa diberikan lembar kerja siswa dan melakukan diskusi bersama kelompoknya. Kemudian siswa mencatat jawaban 
Dwi Wijayanti, Murtono, dan Lintang Kironoratri

PENINGKATAN HASIL BELAJAR SISWA MELALUI MODEL QUANTUM TEACHING ....

WASIS: Jurnal Ilmiah Pendidikan. Volume 1 Nomor 2, November 2020, hlm. 80-85

dann mempresentasikan di depan kelas. Kegiatan selanjutnya yaitu tahap melakukan permainan dengan menggunakan media PALANG ARAHKU yang terdiri dari beberapa kartu. Diantara kartu tersebut terdapat kartu pertanyaan, kartu zonk, dan kartu kejutan. Dalam pelaksanaannya siswa melempar dadu dan berjalan sesuai angka dadu yang didapat. Kemudian siswa mengambil kartu sesuai posisi yang ditempati. Tahap terakhir siswa yang sampai finish terlebih dahulu menjadi pemenang dan berhak mendapat reward.

\section{Hasil Keterampilan Mengajar Guru}

Keterampilan mengajar guru sangat menentukan terwujudnya proses pembelajaran yang terjadi agar dapat sesuai dengan tujuan yang diharapkan. Hal tersebut sejalan dengan pendapat Sanjaya (2006) keterampilan dasar mengajar bagi guru diperlukan agar guru dapat melaksanakan perannya dalam pengelolaan proses pembelajaran, sehingga pembelajaran akan berjalan secara efektif. Keterampilan dasar yang harus dimiliki guru hakikatnya terkait dengan sejauh mana guru dalam menerapkan variasi metode pembelajaran variasi metode mengajar.

Berdasarkan temuan yang ada menunjukkan bahwa pemberian materi yang sesuai dengan kehidupan nyata membuat siswa akan lebih mudah dalam menerima pembelajaran, daripada pemberian materi yang belum pernah didengar atau dilihat oleh siswa. Oleh karena itu, pembelajaran konstektual mengaitkan materi pembelajaran dengan kehidupan nyata siswa.

Kemudian penggunaan media dalam pembelajaran sangat menunjang proses belajar yang terjadi. Dengan adanya media mampu mengaktifkan siswa, memudahkan guru dalam menyampaikan materi atau informasi sekaligus memudahkan siswa dalam menangkap informasi yang disampaikan (Indriasih dkk, 2020). Oleh karena itu penggunaan media yang tepat mampu mencapai tujuan pembelajaran.

Hasil lembar observasi keterampilan mengajar guru yang dilaksanakan menunjukkan setiap siklus mengalami peningkatan dibandingkan dengan sebelum tindakan (pra siklus). Peningkatan keterampilan guru dapat dilihat pada Gambar 1 berikut.

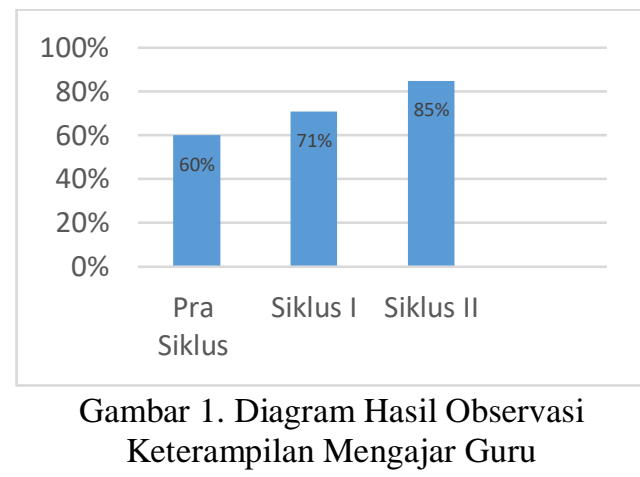

Berdasarkan Gambar 1, keterampilan mengajar guru mengalami peningkatan antar siklus dan setiap siklus memiliki tingkat kebehasilan yang berbeda. Peningkatan tersebut menunjukkan bahwa guru telah melakukan kinerjanya dengan cukup maksimal selama proses pembelajaran berlangsung dengan menggunakan model pembelajaran Quantum teaching berbantuan media PALANG ARAHKU.

\section{Hasil Belajar Ranah Pengetahuan Siswa}

Hasil Belajar diperoleh setelah proses pembelajaran berlangsung. Hasil belajar ranah pengetahuan menurut Anderson dan Krathwohl (dalam Widoyoko, 2014) terdapat 6 indikator hasil belajar pada ranah pengetahuan, yaitu mengingat (C1), memahami (C2), menerapkan (C3), menganalisis (C4), mengevaluasi (C5), mencipta (C6). Rekapitulasi peningkatan ketuntasan hasil belajar ranah pengetahuan dapat dilihat pada Gambar 2 berikut.

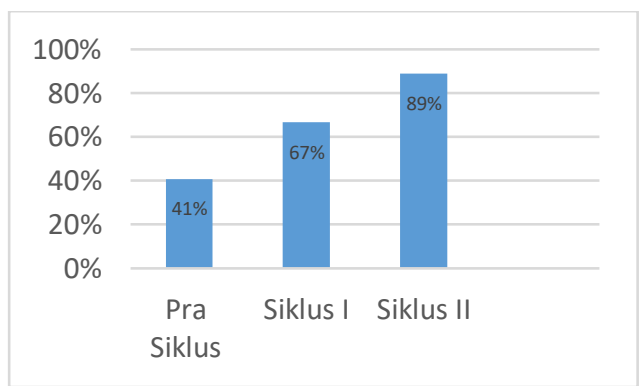

Gambar 2. Diagram Peningkatan Ketuntasan Hasil Belajar Ranah Pengetahuan.

Berdasarkan hasil penelitian, diketahui terdapat beberapa siswa yang masih kesulitan dalam bermain media PALANG ARAHKU dikarenakan siswa kurang memperhatikan arahan dan cara main yang diajarkan oleh guru, permainan tersebut masih sangat asing dalam kehidupan siswa, dan pada saat menjawab pertanyaan banyak siswa yang belum menguasai materi sehingga tidak dapat menjawab dengan 
tepat. Retno, dkk (2018) mengemukakan bahwa siswa memerlukan waktu untuk beradaptasi saat mengikuti pembelajaran dengan menggunakan model ataupun media pembelajaran baru. Berdasarkan hasil refleksi tersebut maka perlu dilakukan perbaikan dalam bentuk pengoptimalan kegiatan dalam pembelajaran. Pengoptimalan dilaksanakan dengan memberikan perhatan penuh kepada seluruh siswa agar terjadi interaksi yang mampu mendorong siswa untuk aktif, tidak takut dalam menyampaikan pendapatnnya.

Setelah diadakan tindakan perbaikan dengan menggunakan model Quantum teaching berbantuan media PALANG ARAHKU terlihat siswa tidak bingung saat bermain media PALANG ARAHKU, siswa sudah mulai aktif dalam diskusi kelompok, dan siswa berani menyampaikan pendapatnya dari hasil diskusi kelompok. Pengoptimalan model Quantum teaching menunjukkan adanya peningkatan hasil belajar ranah pengetahuan siswa secara klasikal. Hal ini sesuai dengan hasil penelitian yang telah dilakukan oleh Ithri dan Suprayitno (2018) bahwa penerapan model pembelajaran Quantum teaching dapat meningkatkan perolehan hasil belajar siswa karena siswa aktif dalam kegiatan pembelajaran. Keaktifan siswa dalam pembelajaran akan memberikan dampak positif terhadap peningkatan hasil belajar siswa.

\section{Hasil Belajar Ranah Keterampilan Siswa}

Hasil belajar ranah keterampilan diperoleh melalui lembar observasi selama proses pembelajaran berlangsung. Menurut Dyer (dalam Kokasih, 2014) menyatakan ranah psikomotorik memiliki tujuh aspek yang meliputi persepsi, kesiapan, reaksi yang diarahkan, reaksi yang natural, reaksi yang kompleks, adaptasi, dan kreativitas. Namun dalam penelitian ini ranah keterampilan yang dinilai sebanyak 5 indikator yaitu persepsi, kesiapan, reaksi yang diarahkan, reaksi natural, dan adaptasi dimana setiap indikator memiliki nilai maksimal 4.

Hasil yang telah diperoleh menunjukkan peningkatan pada setiap siklus. Hasil peningkatan dapat dilihat pada Gambar 3 berikut.

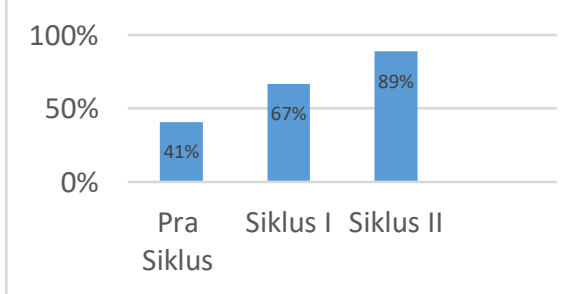

Gambar 3. Diagram Peningkatan Hasil Belajar Ranah Keterampilan Siswa
Berdasarkan data pra siklus persentase yang diperoleh sebesar $42,55 \%$ dengan kriteria kurang. Hasil tersebut belum memenuhi kriteria ketuntasan minimum dan indikator keberhasilan yang telah ditetapkan yaitu $70 \%$.

Sebelum diadakan tindakan (pra siklus) menunjukkan bahwa masih terdapat sebagian siswa yang belum berhasil. Hal tersebut disebabkan oleh beberapa faktor. Seperti yang dikemukakan oleh Susanto (2013) bahwa faktor yang mempengaruhi hasil belajar ada dua faktor yaitu faktor internal dan eksternal. Faktor internal meliputi kecerdasan, minat dan perhatian, motivasi belajar, ketekunan, sikap, kebiasaan belajar, serta kondisi fisik dan kesehatan. Sedangkan faktor eksternal meliputi keluarga, sekolah, dan masyarakat. Penerapan model pembelaran Quantum teaching dan media PALANG ARAHKU diharapkan dapat membantu meningkatkan hasil belajar siswa.

Setelah dilakukan tindakan melalui siklus I dan siklus II dengan menggunakan model Quantum teaching dan media PALANG ARAHKU, hasil belajar ranah keterampilan mengalami peningkatan baik secara individu maupun secara klasikal. Berdasarkan hasil lembar observasi ranah keterampilan siswa memperoleh rata-rata persentase sebesar $67,84 \%$ dengan kriteria baik. Sedangkan pada siklus II hasil lembar observasi ranah keterampilan siswa siklus II hasil rata-rata persentase yang diperooleh naik menjadi 77,27\% kriteria baik. Berdasarkan hasil tersebut menunjukkan bahwa siswa sudah berani bertanya dan menjawab. Hal tersebut sesuai dengan hasil penelitian Merthayasa, dkk (2016) bahwa penerapan model Quantum Teaching mampu mengaktifkan siswa untuk bertanya maupun menjawab pertanyaan. Permasalahan tersebut dikarenakan kurangnya pemahaman dan rasa ingin tahu. Namun, masih terlihat dalam merespon guru siswa belum mampu menyampaikan pertanyaan atau jawaban yang kritis. Hal tersebut berdampak pada proses berpikir siswa. Upaya untuk mengatasi permasalahan tersebut guru perlu memberikan stimulasi agar siswa mempunyai rasa ingin tahu yang lebih kuat. Hal ini dapat ditingkatkan dengan cara membiasakan siswa dengan kegiatan belajar aktif.

\section{SIMPULAN}

Berdasarkan hasil penelitian yang dilakukan secara keseluruhan terjadi peningkatan hasil belajar siswa dengan menggunakan model Quantum teaching berbantuan media PALANG ARAHKU pada siswa kelas IV SDN 1 
Dwi Wijayanti, Murtono, dan Lintang Kironoratri

PENINGKATAN HASIL BELAJAR SISWA MELALUI MODEL QUANTUM TEACHING ....

WASIS: Jurnal Ilmiah Pendidikan. Volume 1 Nomor 2, November 2020, hlm. 80-85

Gondoharum dan memenuhi indikator keberhasilan yang telah ditentukan. Hasil penelitian pada siklus I ranah pengetahuan siswa muatan IPS dan Bahasa Indonesia secara klasikal memperoleh $68,7 \%$ (baik). Kemudian meningkat pada siklus II menjadi 86,99\% (sangat baik). Hasil belajar siswa ranah keterampilan siklus I memperoleh persentase $71,5 \%$ (baik). Kemudian meningkat pada siklus II menjadi 87,5 \% (sangat baik). Hasil keterampilan mengajar guru mengalami peningkatan. Pada siklus I memperoleh persentase $71 \%$ (baik) dan siklus II meningkat menjadi $85 \%$ (sangat baik).

\section{DAFTAR PUSTAKA}

Amalia, S. R., Fakhriyah, F., \& Ardianti, S.D. (2020). Peningkatan Kemampuan Berpikir Kritis Siswa Melalui Model Problem Based Learning Berbantuan Media Kotak Kehidupan Pada Tema 6 Cita-Citaku. WASIS: Jurnal Ilmiah Pendidikan, 1(1), 713

Aqib. Zainal. 2013. Model-model, media, dan Strategi Pembelajaran Konstekstual (Inovatif). Bandung: CV Yrama Widya.

Ardianti, S. D. (2015). Pengaruh Modul Tematik Inquiry-Discovery Terhadap Hasil Belajar Siswa Materi Metabolisme Pembentuk Bioenergi. Refleksi Edukatika: Jurnal Ilmiah Kependidikan, 5(2).

Diantoro, C. T., Ismaya, E. A., \& Widianto, E. (2020). Peningkatan Hasil Belajar Siswa Melalui Model Quantum Teaching Berbantuan Media Aplikasi Edmodo Pada Siswa Sekolah Dasar. WASIS: Jurnal Ilmiah Pendidikan, 1(1), 1-6.

Indriasih, A., Sumaji, S., Badjuri, B., \& Santoso, S. (2020). Pengembangan E-Comic Sebagai Media Pembelajaran Untuk Meningkatkan Kecakapan Hidup Anak Usia Dini. Refleksi Edukatika: Jurnal Ilmiah Kependidikan, 10(2), 154-162.

Ithri, R. Z., \& Suprayitno. 2018. Penerapan Model Quantum Teaching untuk Meningkatkan Hasil Belajar Muatan Materi IPS Kelas IV SDN Putat Jaya 2 Surabaya. JPGSD. Vol. 6, No. 2, 135-138

Kariadinata, Abdurahman. 2015. Dasar-dasar Statistik Pendidikan. Bandung: CV. Pustaka Setia.
Kokasih, E. 2014. Strategi Belajar dan Pembelajaran Implementasi Kurikulum 2013. Bandung: Yrama Widya.

Merthayasa W, I Nyoman, dkk. 2016. Penerapan Model Quantum Teaching untuk Meningkatkan Hasil Belajar Bahasa Indonesia (Keterampilan Menulis) pada Siswa Kelas IV SD. e-Journal PGSD Universitas Pendidikan Ganesha, Vol. 1, No. 1, 1-10

Murtono, 2017. Merencanakan dan Mengelola Model-Model Pembelajaran Inovatif. Ponorogo: WADE Group.

Pratiwi, I.A., Ardianti, S.D., \& Kanzunnudin, M. (2018). Peningkatan Kemampuan Kerjasama Melalui Model Project Based Learning (PjBL) Berbantuan Metode Edutainment Pada Mata Pelajaran Ilmu Pengetahuan Sosial. Jurnal Refleksi Edukatika, 8(2), hlm. 177-182.

Retno, R. S., \& Marlina, D. (2018). Implementasi Sets (Sceince, Environment, Technology, Social) Terhadap Literasi Sains Siswa Sdn 02 Mojorejo Madiun. Refleksi Edukatika: Jurnal Ilmiah Kependidikan, 9(1).

Sanjaya, 2016. Strategi Pembelajaran Berorientasi Standar Proses Pendidikan. Jakarta: Kencana.

Shoimin, Aris. 2014. 68 Model Pembelajaran Inovatif dalam Kurikulum 2013. Yogyakarta: Graha Ilmu.

Sumadayo, Samsu. 2013. Penelitian Tindakan Kelas. Yogyakarta: Graha Ilmu.

Susanto, Ahmad. 2013. Teori Belajar dan Pembelajaran di Sekolah Dasar. Jakarta: Prenadamedia Group. 